\title{
Tool for Measuring the Influence of the Field of Knowledge on Entrepreneurial Intention among University Students
}

\author{
Luisa Díez-Echavarría1*, Alejandro Valencia-Arias², Jonathan Bermúdez-Hernández² \\ 1 Departamento de Finanzas, Facultad de Ciencias Económicas y Administrativas, Instituto Tecnológico Metropolitano, \\ Calle 54 A \#30-01, Medellín, Colombia \\ 2 Departamento de Ciencias Administrativas, Facultad de Ciencias Económicas y Administrativas, Instituto Tecnológico \\ Metropolitano, Calle 54 A \#30-01, Medellín, Colombia \\ *Corresponding author, e-mail: luisadiez@itm.edu.co
}

Received: 30 July 2018, Accepted: 05 July 2019, Published online: 31 December 2019

\begin{abstract}
This paper aims to analyze a measurement tool allowing the identification of the differences that may exist between the factors and their relationships that affect the entrepreneurial intention of undergraduate students from related and non-business-related programs. This is to know what elements motivate to create a company for each group, and their degree of association, in order to design more effective educational strategies focused on their motivations. For this, a model was proposed, which was validated through the application of a self-administered questionnaire to undergraduate students of different careers, in Instituto Tecnológico Metropolitano (Medellín). It was found that personal attitudes have a stronger relationship with entrepreneurial intention in students of business-related programs, while perceived viability, perceived convenience, and entrepreneurial behavior have greater weight in students from non-affiliated programs. Thus, the courses focused on creativity in the first group, and the courses focused on the know-how in the second group would be more efficient in increasing the entrepreneurial intention.
\end{abstract}

Keywords

entrepreneurial intention, Theory of Planned Behavior, higher education, field of knowledge

\section{Introduction}

Society recognizes the importance of creating new businesses, regardless of their characteristics, because businesses generate wealth and well-being among the population (SoriaBarreto et al., 2016b). A variety of research has, therefore, been carried out to try to understand the entrepreneurial process in different fields and contexts, to create environments that encourage it (Cadavid et al., 2017; Hernández-López et al., 2018). Nevertheless, gaps in this subject still remain.

Higher Education Institutions (HEIs) deserve special attention because the businesses started by entrepreneurs educated in such institutions are more likely to have a significant impact on economic growth (Echeverri-Sánchez et al., 2018; Torres Velásquez et al., 2018) and the entrepreneurs are more likely to perceive new entrepreneurial ideas and act accordingly, compared to other population groups (Naktiyok et al., 2010). Also, entrepreneurship education can stimulate entrepreneurial intention (EI) in students (Jones et al., 2011; Mejía Ordoñez et al., 2017; Packham et al., 2010; Soria-Barreto, et al., 2016a).
This study explores and compares the possible differences in EI and the factors that explain them to university students in programs related to administration and other programs.

\section{Theoretical framework}

\subsection{Model used to evaluate entrepreneurial intention} In the field of research on topics related to entrepreneurship, one of the predominant theories is the Theory of Planned Behavior (TPB) (Ajzen, 1991; Schifter and Ajzen, 1985), which explains that the best way to determine whether an individual will act in a certain way is through his or her intention (Van Gelderen et al., 2015). This theory attempts to explain the behavior of individuals based on the beliefs-attitude and intention-behavior relationship. It is an extension of the Theory of Reasoned Action (Ajzen and Fishbein, 1980) and is focused on those types of behavior in which the subject does not have complete control, but rather is influenced to some extent by non-volitional 
factors related to the presence of certain requirements and resources (Moreno-Agudelo and Valencia-Arias, 2017; Sampedro et al., 2013; Villa et al., 2018).

It is understood that intentions to carry out different kinds of behavior can be predicted with great accuracy based on attitudes toward the behavior, subjective norms and perceived behavioral control; these intentions, together with the perception of behavioral control, represent a considerable variation in actual behavior (Ajzen, 1991; Marulanda Valencia et al., 2014). Attitudes, subjective norms, and perceived behavioral control are related to sets of emphasized behaviors, norms, and beliefs about behavioral control (Ajzen, 1991). It is assumed that if people display similar features or constructs, their behavior in terms of entrepreneurship is also similar.

Thus, models based on intentions present constructs with high predictive power for explaining entrepreneurial behavior (Botsaris and Vamvaka, 2012), and for this reason have been widely used since the early 1990s, confirming their importance and applicability to diverse contexts (Liñán and Fayolle, 2015).

\subsection{Proposed model}

The behaviors of an entrepreneur include starting businesses, identifying business opportunities and opening, managing, and maintaining businesses (Yurrebaso Macho, 2012). It is important to identify the factors that play a role in starting, maintaining and finalizing a specific behavior since this behavior is influenced by different psychological processes of the individual (Breva Asensio and Carpi Ballester, 2001).

The proposed model, therefore, measures five main variables: personal attitudes toward the behavior, entrepreneurial behavior, perceived viability, perceived convenience, and entrepreneurial intention.

Personal attitudes influence the perceived convenience that potential entrepreneurs may have on the business creation process, this is explained by the positive attitude they develop as they accumulate more positive experiences throughout their personal experience (Hong et al., 2012). This supports the hypothesis $\mathrm{H} 1$ to $\mathrm{H} 4$ :

H1: Personal attitudes (PA) influences in Entrepreneur Behavior (EB).

$\mathrm{H} 2$ : Personal attitudes (PA) influences in Perceived Convenience (PC).

H3: Personal attitudes (PA) influences in Entrepreneurial Intention (EI)
H4: Personal attitudes (PA) influences in Perceived Feasibility (PF).

Additionally, van Dam et al. (2010) affirm that entrepreneurial behavior implies resources management take advantage of recognized opportunities so that those experiences and past behaviors make an influence in perceived convenience to create a company. Thus, the following hypotheses are presented:

H5: Entrepreneur Behavior (EB) influences in Perceived Convenience (PC)

H6: Entrepreneur Behavior (EB) influences in Entrepreneurial Intention (EI)

H7: Entrepreneur Behavior (EB) influences in Perceived Feasibility (PF).

Also, it has been shown perceived viability has the capacity to predict entrepreneurial intention, encouraging greater proactivity and greater attraction for creating a company (Sánchez García et al., 2005). Likewise, it has been observed the relationship between perceived convenience and perceived viability (Díaz-Casero et al., 2012). This sustains the following hypothesis:

H8: Perceived Feasibility (PF) influences in Perceived Convenience (PC)

H9: Perceived Feasibility (PF) influences in Entrepreneurial Intention (EI)

H10: Perceived Convenience (PC) influences in Entrepreneurial Intention (EI)

The model on which the research was based is illustrated in Fig. 1.

\section{Methodology}

\subsection{Data collection}

Cross-cutting, correlational-causal research was carried out, in which a quantitative tool in the form of a self-administered questionnaire was used to collect the data

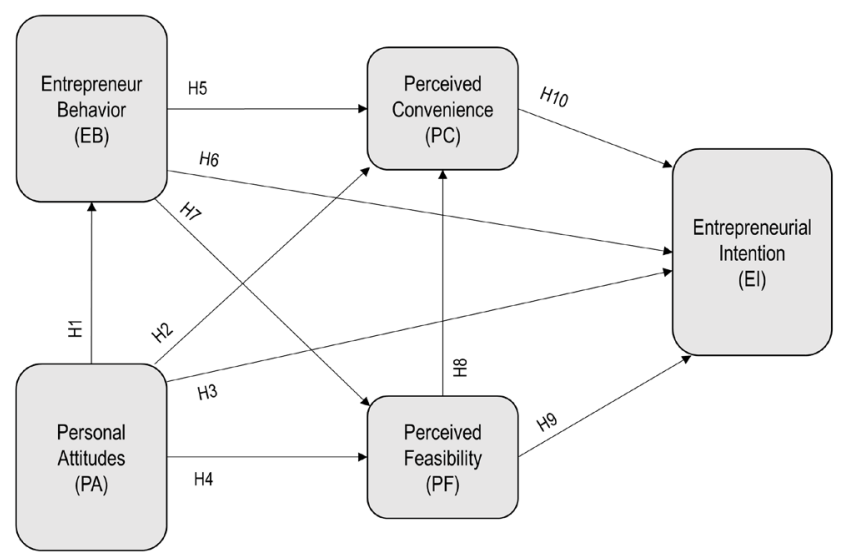

Fig. 1 Proposed model 
needed to validate the model. Since not all programs at the HEIs include mandatory courses in entrepreneurship and thus those who register for these courses do so voluntarily, it is understood that students already have some interest in the business creation process before taking the courses. When evaluating the effect that education has on EI, it is, therefore, necessary to differentiate the population of students with some interest in entrepreneurship (those who take courses on the subject) from those who do not necessarily have such an interest.

The tool was designed based on questions that have been validated in other studies. It includes a total of 24 questions and was applied to 552 active students at the Instituto Tecnológico Metropolitano, selected by convenience, of which 229 were registered in programs related to administration and 323 to other unrelated programs. A five-point Likert scale was used to measure the factors proposed in the model, where those surveyed indicate their level of agreement or disagreement for each element.

Entrepreneur Behavior was measured through the three questions such as: "I can develop and keep favorable relationships with investors" and "I can generate strategies to look for market opportunities" (adapted from (Naktiyok et al., 2010:p.428)). Personal Attitudes were measured through 2 items "It is attractive to become an entrepreneur" and "Being an entrepreneur would give great satisfaction" (adapted from (Iakovleva et al., 2011:p.369; Liñán et al., 2013:p.101)).

To measure Perceived Convenience, three items were used. Some examples are: "Creating a company can improve the balance between work and private life" and "Being a businessman implies more advantages than disadvantages" (adapted from (Liñán et al., 2013:p.101). Regarding the construct Perceived Feasibility, three items were considered, for example: "It depends on me whether or not I become an entrepreneur" and "I am ready and I can create a new company" (adapted from (Iakovleva et al., 2011:p.369; Marques et al., 2012:p.667). Finally, Entrepreneurial Intention was measured through 4 items. Some examples of these items are: "Professional goal is to be an entrepreneur" and "I will do everything possible to create a company" (adapted from (Liñán et al., 2013:p.101).

Questionnaires with scales are currently the mostused data collection technique in social research because they are effective, low-cost tools that make it possible to evaluate a large number of people with relative ease, and also enable analysis and understanding of the behavior of variables that would otherwise be difficult to achieve
(Arango-Botero et al., 2019). They also make it possible to obtain appropriate descriptions and categorical data and, when adequately carried out, to generalize these (González and Scublinsky, 2011).

Data collected for each construct was validated through convergent and discriminant processes (each with its own statistical evidence), and the final model was subsequently defined through Somers' D statistic which measures the degree of association between the different constructs (Valencia-Arias et al., 2019). The results are presented in three different groups: the general model, comprising all of the data; model 1, which includes only the data for the students in programs related to administration; and model 2, which includes only the data for the students in programs not related to administration. All calculations for this study were made using SPSS software.

\subsection{Convergent validity}

The validity of the measurement scales used, along with each of the constructs and the tool in general, was confirmed through the statistical method of confirmatory factor analysis. This is a set of diverse technical procedures for studying the relationship of interdependence among a set of variables, to group them according to "shared variability" and of uncovering the underlying structures (factors), latent dimensions or concepts, thereby achieving the goal of summarizing and reducing the data. This statistical technique is highly useful if the multidimensionality of a construct is being evaluated because it allows for an empirical exploration, considering that the objective is to select those items that most correlate with the set of items the construct is measuring (Mora, 2005).

Moreover, the reliability of the model was recognized as the degree to which a tool measures precisely and without error, and indicates the condition of reliability; in other words, when utilized repeatedly it is capable of providing results that are true and constant in similar conditions of measurement (Arribas, 2004). It must be assessed on two levels: the reliability of the observable items and the reliability of the constructs (Calvo-Porral et al., 2013). With regards to its value in academic terms, it has been stated that a value greater than 0.6 is considered evidence that the model is reliable (Bagozzi and Yi, 1988).

Also, the reliability of the constructs refers to the degree to which an observable variable reflects a factor, where a value greater than 0.7 is considered acceptable (Hair et al., 2001). Therefore, convergent validity evaluates the degree to which the measurements of the items 
grouped by a single concept are correlated (Calvo-Porral et al., 2013). It was not necessary to eliminate any indicators because its standardized factor loading gave results that were in line with the literature that was consulted, and average loading was greater than 0.7 for all constructs, as shown in Table 1.

Bartlett's test of sphericity and the KMO measure of sampling adequacy were subsequently calculated, and the level of conditioning of the model was determined to carry out a factor analysis. Bartlett's test of sphericity opposes the null hypothesis that the observed correlation matrix is, in fact, an identity matrix. Given that the Bartlett values are less than 0.05 in the model proposed in this study, it can be confirmed that significant correlations exist between the variables.

In the same manner, the value of the Kaiser-MeyerOlkin (KMO) measure of sampling adequacy is defined as an index that compares the magnitudes of the observed correlation coefficients to the magnitudes of the partial correlation coefficients. Its value is between 0 and 1 , where higher is better, and values above 0.5 are accepted (Lévy et al., 2006).

Table 2 shows that the coefficients for each of the constructs meet the criteria above, indicating that it is feasible to employ the data reduction technique, or in other words, to obtain the minimum explanatory elements (factors) capable of clarifying the facts about what influences entrepreneurial processes.

Table 1 Convergent validity of standardized factor loading

\begin{tabular}{|c|c|c|c|}
\hline Construct & Item & $\begin{array}{c}\text { Standardized } \\
\text { factor loadings }\end{array}$ & $\begin{array}{c}\text { Average } \\
\text { standardized } \\
\text { factor loadings }\end{array}$ \\
\hline \multirow{2}{*}{$\begin{array}{l}\text { Personal } \\
\text { Attitudes }\end{array}$} & PA1 & 0.863 & \multirow{2}{*}{0.863} \\
\hline & PA2 & 0.863 & \\
\hline \multirow{3}{*}{$\begin{array}{l}\text { Entrepreneur } \\
\text { Behavior }\end{array}$} & EB1 & 0.711 & \multirow{3}{*}{0.747} \\
\hline & EB2 & 0.780 & \\
\hline & EB3 & 0.749 & \\
\hline \multirow{3}{*}{$\begin{array}{l}\text { Perceived } \\
\text { Convenience }\end{array}$} & PC1 & 0.706 & \multirow{3}{*}{0.768} \\
\hline & PC2 & 0.805 & \\
\hline & PC3 & 0.793 & \\
\hline \multirow{4}{*}{$\begin{array}{l}\text { Entrepreneurial } \\
\text { Intention }\end{array}$} & EI1 & 0.761 & \multirow{4}{*}{0.831} \\
\hline & $\mathrm{EI} 2$ & 0.779 & \\
\hline & EI3 & 0.894 & \\
\hline & EI4 & 0.889 & \\
\hline \multirow{3}{*}{$\begin{array}{l}\text { Perceived } \\
\text { Feasibility }\end{array}$} & PF1 & 0.493 & \multirow{3}{*}{0.707} \\
\hline & PF2 & 0.810 & \\
\hline & PF3 & 0.819 & \\
\hline
\end{tabular}

Table 2 Convergent validity of KMO and Bartlett's sphericity test

\begin{tabular}{lccc}
\hline Factor & KMO value & $\begin{array}{c}\text { Bartlett } \\
\text { value }\end{array}$ & $\begin{array}{c}\text { Meets } \\
\text { criteria }\end{array}$ \\
\hline Personal Attitudes & 0.500 & 0.00 & Yes \\
Entrepreneur Behavior & 0.633 & 0.00 & Yes \\
Perceived Convenience & 0.640 & 0.00 & Yes \\
Entrepreneurial Intention & 0.674 & 0.00 & Yes \\
Perceived Feasibility & 0.552 & 0.00 & Yes \\
\hline
\end{tabular}

\subsection{Discriminant validity}

Discriminant validity refers to the fact that each factor must represent a different dimension, and for this, each observable variable must be loaded onto a single factor. Thus, the further the value of phi is from 1 , the greater the discriminant validity will be (Lévy et al., 2006).

It was confirmed that the confidence interval in the estimate of the correlation between each pair of factors did not contain the value of 1 (Anderson and Gerbing, 1988). Table 3, Table 4 and Table 5 demonstrate that all cases comply with discriminant validity.

Table 3 Discriminant validity of the general measurement model

\begin{tabular}{cccccc}
\hline & PA & EB & PC & EI & PF \\
\hline PA & $\ldots$ & & & & \\
EB & {$[0.384 ; 0.527]$} & $\ldots$ & & & \\
PC & {$[0.402 ; 0.539]$} & {$[0.366 ; 0.512]$} & $\ldots$ & & \\
EI & {$[0.527 ; 0.654]$} & {$[0.449 ; 0.583]$} & {$[0.396 ; 0.543]$} & $\ldots$ & \\
PF & {$[0.354 ; 0.494]$} & {$[0.434 ; 0.569]$} & {$[0.334 ; 0.496]$} & {$[0.485 ; 0.621]$} & $\ldots$ \\
\hline
\end{tabular}

Headings are related to the construct's names.

Table 4 Discriminant validity of the related-to-administration measurement model (model 1)

\begin{tabular}{cccccc}
\hline & PA & EB & PC & EI & PF \\
\hline PA & $\ldots$ & & & & \\
EB & {$[0.281 ; 0.666]$} & $\ldots$ & & & \\
PC & {$[0.123 ; 0.575]$} & {$[0.184 ; 0.608]$} & $\ldots$ & & \\
EI & {$[0.354 ; 0.742]$} & {$[0.199 ; 0.627]$} & {$[0.066 ; 0.504]$} & $\ldots$ & \\
PF & {$[0.310 ; 0.669]$} & {$[0.359 ; 0.724]$} & {$[0.109 ; 0.540]$} & {$[0.148 ; 0.596]$} & $\ldots$ \\
\hline
\end{tabular}

Headings are related to the construct's names.

Table 5 Discriminant validity of the non-related-to-administration measurement model (model 2)

\begin{tabular}{cccccc}
\hline & PA & EB & PC & EI & PF \\
\hline PA & $\ldots$ & & & & \\
EB & {$[0.386 ; 0.560]$} & $\ldots$ & & & \\
PC & {$[0.388 ; 0.566]$} & {$[0.350 ; 0.548]$} & $\ldots$ & & \\
EI & {$[0.495 ; 0.666]$} & {$[0.489 ; 0.645]$} & {$[0.389 ; 0.572]$} & $\ldots$ & \\
PF & {$[0.270 ; 0.479]$} & {$[0.428 ; 0.602]$} & {$[0.333 ; 0.517]$} & {$[0.504 ; 0.658]$} & $\ldots$ \\
\hline
\end{tabular}


The reliability of the measurement scale was later identified, and the explanatory capacity of the model was verified by calculating Cronbach's alpha for the respective scales of each construct. This value fluctuates between 0 and 1 ; the closer it is to 1 , the greater the internal consistency of the analyzed items.

As shown in Table 6, the measurement tool appears to have adequate reliability in the internal consistency of the measurement scale, given that all values are within the range recommended by the authors previously mentioned.

The results of the confirmatory analysis demonstrate the existence of a sustainable factor model for analysis based on the perceptions of the students surveyed regarding the factors that influence the intention of creating a business. The presence of convergent validity and discriminant validity within the tool, combined with acceptable reliability, confirms that the tool evaluates fundamental variables that directly or indirectly influence the ideas, expectations, and motivations for entrepreneurial behavior among the people surveyed in this study.

Table 6 Feasibility Index - Cronbach's Alpha for three models.

\begin{tabular}{lccc}
\hline Factor & $\begin{array}{c}\text { General } \\
\text { model }\end{array}$ & $\begin{array}{c}\text { Model 1. } \\
\text { Related-to- } \\
\text { administration }\end{array}$ & $\begin{array}{c}\text { Model 2. } \\
\text { Non-related-to- } \\
\text { administration }\end{array}$ \\
\hline $\begin{array}{l}\text { Personal } \\
\text { Attitudes }\end{array}$ & 0.873 & 0.908 & 0.866 \\
$\begin{array}{l}\text { Entrepreneur } \\
\text { Behavior }\end{array}$ & 0.787 & 0.925 & 0.763 \\
$\begin{array}{l}\text { Perceived } \\
\text { Convenience }\end{array}$ & 0.816 & 0.758 & 0.804 \\
$\begin{array}{l}\text { Entrepreneurial } \\
\text { Intention }\end{array}$ & 0.902 & 0.918 & 0.895 \\
$\begin{array}{l}\text { Perceived } \\
\text { Feasibility }\end{array}$ & 0.763 & 0.786 & 0.761 \\
\hline
\end{tabular}

\section{Results}

Estimation was carried out of the structural model proposed for identifying factors influencing the entrepreneurial intention of the reference population, where the variously proposed hypotheses are brought together, and their degree of association is measured using Somers' D statistic. This is a measurement of association between two ordinal variables that fluctuates between -1 (as the values of one variable increase, those of the other decrease) and 1 (as the values of one variable increase, those of the other increase as well) and values close to zero indicate that there is little or no relationship between the two variables (López-Roldán and Fachelli, 2015).

The values for each of the evaluated statistics and the validated model can be found in Table 7. In accordance with López-Roldán and Fachelli (2015), it can be concluded that all of the null hypotheses considered in the model are consistent with what was intended to be evaluated.

Somers' D coefficient was inserted into a table of crossed factors in order to observe the degree of association between the variables that made up the hypotheses and those that did not, with the aim of not only confirming the degree of association for hypothetical relationships, but also of corroborating how the association between the other constructs that make up the model behaves. Table 8, Table 9 and Table 10 show all of the relationships established between the variables of the model, and it can be observed that only hypothesis 10 is rejected in model 1 (Table 2) for having a value of less than 0.3 (0.277) (Sánchez Ramos, 2005).

In Fig. 2, Fig. 3 and Fig. 4 the proposed model is presented with its respective values of associativity between the variables, and it is applied to the three different groups of data.

Table 7 Contrast of hypotheses. Degree of association of factors

\begin{tabular}{|c|c|c|c|c|}
\hline & Hypothesis & General model & $\begin{array}{l}\text { Model } 1 . \\
\text { Related-to-administration }\end{array}$ & $\begin{array}{c}\text { Model } 2 . \\
\text { Non-related-to-administration }\end{array}$ \\
\hline H1 & Personal Attitudes -> Entrepreneur Behavior & 0.439 & 0.508 & 0.442 \\
\hline $\mathrm{H} 2$ & Personal Attitudes -> Perceived Convenience & 0.463 & 0.377 & 0.446 \\
\hline $\mathrm{H} 3$ & Personal Attitudes -> Entrepreneurial Intention & 0.594 & 0.597 & 0.56 \\
\hline $\mathrm{H} 4$ & Personal Attitudes -> Perceived Feasibility & 0.416 & 0.544 & 0.357 \\
\hline H5 & Entrepreneur Behavior -> Perceived Convenience & 0.400 & 0.352 & 0.404 \\
\hline H6 & Entrepreneur Behavior -> Entrepreneurial Intention & 0.478 & 0.392 & 0.525 \\
\hline $\mathrm{H} 7$ & Entrepreneur Behavior -> Perceived Feasibility & 0.457 & 0.506 & 0.472 \\
\hline $\mathrm{H} 8$ & Perceived Feasibility -> Perceived Convenience & 0.381 & 0.324 & 0.387 \\
\hline H9 & Perceived Feasibility -> Entrepreneurial Intention & 0.506 & 0.367 & 0.530 \\
\hline H10 & Perceived Convenience -> Entrepreneurial Intention & 0.433 & 0.277 & 0.441 \\
\hline
\end{tabular}


Table 8 Somers' D. General model

\begin{tabular}{lccccc}
\hline & PA & EB & PC & EI & PF \\
\hline PA & 1.000 & & & & \\
EB & 0.439 & 1.000 & & & \\
PC & 0.463 & 0.400 & 1.000 & & \\
EI & 0.594 & 0.478 & 0.433 & 1.000 & \\
PF & 0.416 & 0.457 & 0.381 & 0.506 & 1.000 \\
\hline
\end{tabular}

Table 9 Somers' D. Related-to-administration model (Model 1)

\begin{tabular}{cccccc}
\hline & PA & EB & PC & EI & PF \\
\hline PA & 1.000 & & & & \\
EB & 0.508 & 1.000 & & & \\
PC & 0.377 & 0.352 & 1.000 & & \\
EI & 0.597 & 0.392 & 0.277 & 1.000 & \\
PF & 0.544 & 0.506 & 0.324 & 0.367 & 1.000 \\
\hline
\end{tabular}

Table 10 Somers' D. Non-related-to-administration model (Model 2)

\begin{tabular}{lccccc}
\hline & PA & EB & PC & EI & PF \\
\hline PA & 1.000 & & & & \\
EB & 0.442 & 1.000 & & & \\
PC & 0.446 & 0.404 & 1.000 & & \\
EI & 0.560 & 0.525 & 0.441 & 1.000 & \\
PF & 0.357 & 0.472 & 0.387 & 0.530 & 1.000 \\
\hline
\end{tabular}

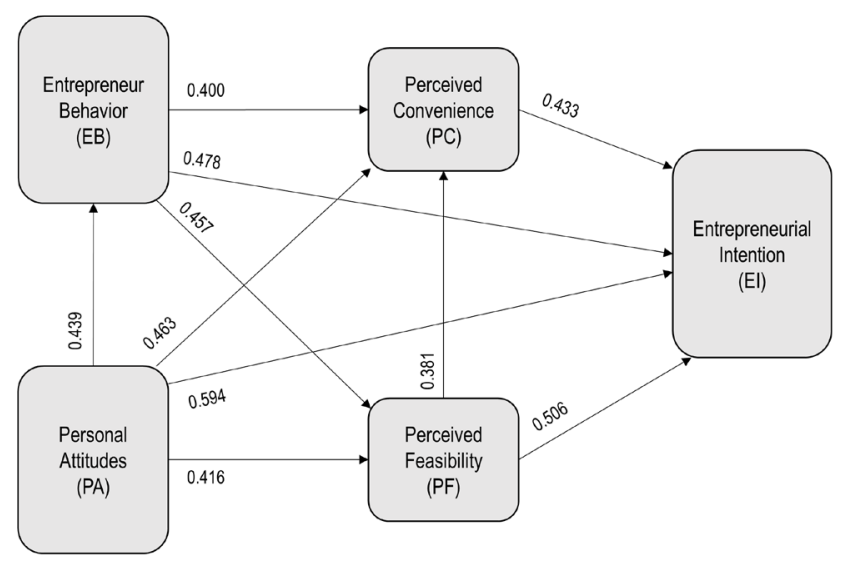

Fig. 2 Somers' D - General model

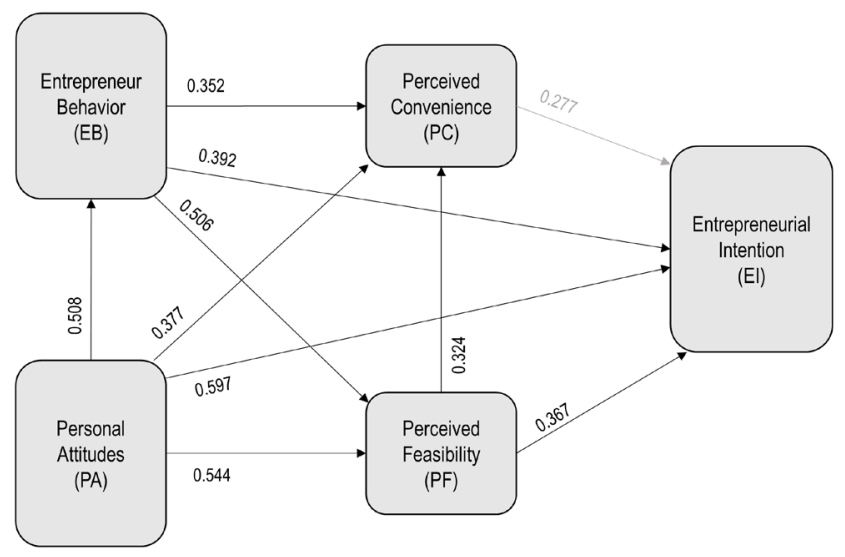

Fig. 3 Somers' D - Related-to-administration model (Model 1)

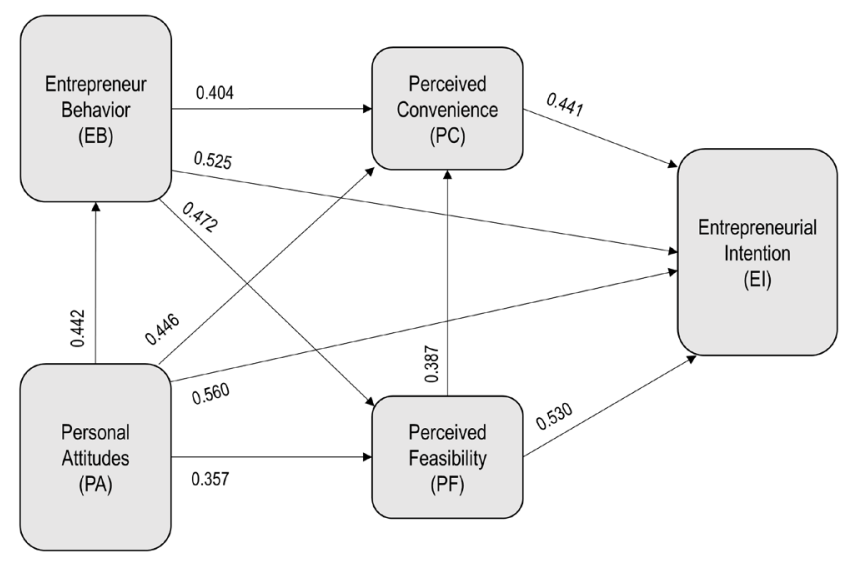

Fig. 4 Somers' D - Non-related-to-administration model (Model 2)

\section{Discussion}

In this study, ten hypotheses regarding university students' intentions to start a business were considered. Models with data from students in programs related to and not related to administration were developed in order to evaluate the effects that education in these fields has on EI. These study programs were selected because although several studies such as (Souitaris et al., 2007; Davey et al., 2011; Solesvik, 2013; Hattab, 2014; Maresch et al., 2016) have evaluated the effect that one-time entrepreneurship courses have on intention, it is possible that such evaluation is biased due to the enthusiasm generated by the project normally developed during the course, and that subsequently dissipates, instead of any serious intention to start up a business (Londoño-Patiño and Acevedo-Álvarez, 2018; Souitaris et al., 2007).

The aforementioned schemes were developed with the aim of predicting both voluntary behaviors and those which are not under exhaustive personal control, because although perceived convenience refers to the perception of internal obstacles (lack of skills or abilities) and external obstacles (lack of accessibility, no collaboration from others), perceived viability adds social context and puts the reference group, that influences the behavioral intention of an individual, at center stage (Ortiz-Delgadillo et al., 2017).

The findings of the study confirm that personal attitudes, perceived viability and entrepreneurial behavior directly and positively influence the entrepreneurial intentions of the students, with the impact of personal attitudes towards such behavior highest in the three analyzed cases. In addition, this construct directly explains the result of the others, given that its increase generates a direct increase in entrepreneurial intention as well as an indirect increase through the other constructs. The existence of this relationship is also presented in the work of (Peterman and Kennedy, 2003; Herrington et al., 2011; Rae, 2010). 
Furthermore, in order to identify the effects that education in management fields has on entrepreneurial intention, it is necessary to compare the results of models 1 and 2 (see Fig. 3 and Fig. 4). To begin, the value of the relationship between personal attitudes and entrepreneurial intention in model $\left.1 \mathrm{H} 3_{1}=0.597\right)^{1}$ is greater than in model $2 \mathrm{H}_{2}$ $=0.560$, suggesting that education in administrative fields strengthens positive attitudes towards entrepreneurship, as also affirmed by (Packham et al., 2010; Hattab, 2014; Tshikovhi and Shambare, 2015). It can also be observed that perceived viability in model 2 has a greater impact on entrepreneurial intention $\left(\mathrm{HO}_{2}=0.530>H 9_{1}=0.367\right)$ and on perceived convenience $\left(H 8_{2}=0.387>H 8_{1}=0.324\right)-$ a result that is coherent with the work of (Hattab, 2014). This can be explained by the fact that students studying administrative subjects are familiar with both the fortunate circumstances and the problems that entrepreneurs must face, thereby diminishing this construct.

These results shed light on the different elements that precede EI and also demonstrate the need for entrepreneurship courses designed with different focuses for these two groups: for group 1 - students in programs related to administration - emphasis should be placed on innovation, creativity and the benefits of becoming an entrepreneur in a developing country, while for group 2 - students in programs not related to administration - emphasis should be placed on technical knowledge that provides greater security for running the business.

After calculating the degree of association for the variables with a relationship established within the model, it was found that the models are comprised of clear relationships; however, it is also evident that those students not connected to programs related to administrative sciences demonstrate a lesser interest in starting their own company.

\section{Conclusions}

This study acknowledges that entrepreneurial intention is a product of diverse environments - economic, social, cultural and others - which are mostly separate from the education system. In order to design effective strategies aimed at increasing the intention to start a business, it is necessary to understand which factors are affecting this intention and to what extent. It was found that the factors that affect entrepreneurial intention do so to a different extent among students in programs related to administration compared to students in other programs; for example, personal attitudes play a greater role among students in programs related to administration while perceived viability is more important to students in unrelated programs. It is important to understand the difference between the two groups since the identification of the most important factors will facilitate the development of programs with different focuses that impact EI more efficiently.

This study and its results take on more relevance in contexts such as that of Latin America, as entrepreneurial intention becomes increasingly necessary in developing regions where economic reactivation through new businesses that create jobs and therefore revitalize the market is required. EI proves even more important when taking into account the barriers to labor market access faced by recent university graduates.

Thus, the challenge faced by education systems and each of their components - and for the context of this study, higher education institutions in particular - lies in guaranteeing that entrepreneurial actions not only be associated with fields related to administrative sciences but that the inclusion of entrepreneurial skills throughout university curricula be encouraged. In the framework of Latin American economies, bringing unutilized labor potential into the workforce requires strengthening these kinds of skills, since the creation of new organizations will facilitate significant improvements in employability rates. Nevertheless, it must be recognized that polishing curricula is not sufficient; for entrepreneurial ideas to become a reality, public policies are also required to stimulate the creation of small, medium and large businesses.

The second stage to this study is proposed in which the level of association between the same constructs would be measured after the two different groups have participated in the entrepreneurship course designed according to their particular characteristics, in order to evaluate the effect of specialized education on each group.

Finally, while this research made it possible to study individual and collective aspects of young university students' perceptions regarding the creation of a business model, for future research the incorporation of protective factors mentioned in the theory of social development proposed by (Hawkins and Weis, 1985) is recommended as a complement to individual attributes (qualities, character strengths) and attributes of the environment (perception of the State or political and legislative climate in which the young person finds him or herself immersed). 


\section{References}

Ajzen, I., Fishbein, M. (1980) "Understanding attitudes and predicting social behavior", Prentice-Hall, Englewood Cliffs, NJ, USA.

Ajzen, I. (1991) "The theory of planned behavior", Orgnizational Behavior and Human Decision Processes, 50(2), pp. 179-211. https://doi.org/10.1016/0749-5978(91)90020-T

Anderson, J. C., Gerbing, D. W. (1988) "Structural Equation Modeling in Practice: A Review and Recommended Two-Step Approach", Psychological Bulletin, 103(3), pp. 411-423. [online] Available at: http://citeseerx.ist.psu.edu/viewdoc/download?doi=10.1.1.540.4887 $\&$ rep $=$ rep1\&type $=$ pdf [Accessed: 10 July 2017]

Arango-Botero, D., Chalela, S., Valencia-Arias, A. (2019) "Development and Validation of a Scale to Measure the Motivation to Pursue a Graduate Course", Integration of Education, 23(2), pp. 196-207. https://doi.org/10.15507/1991-9468.095.023.201902.196-207

Arribas, M. (2004) "Diseño y validación de cuestionarios" (Design and validation of questionnaires), Matronas Profesión, 5(17), pp. 23-29. [online] Available at: http://www.enferpro.com/documentos/validacion_cuestionarios.pdf [Accessed: 29 October 2017] (in Spanish)

Bagozzi, R. P., Yi, Y. (1988) "On the evaluation of structural equation models", Journal of the Academy of Marketing Science, 16(1), pp. 74-94. https://doi.org/10.1007/BF02723327

Botsaris, C. A., Vamvaka, V. (2012) "Models of the determinants of entrepreneurial behaviour: a literature review", Regional Science Inquiry Journal, 4(3), pp. 155-172. [online] Available at: https:// ideas.repec.org/a/hrs/journl/y2012vivi3p155-172.html [Accessed: 31 October 2017]

Breva Asensio, A., Carpi Ballester, A. (2001) "La predicción de la conducta a través de los constructos que integran la teoría de acción planeada" (The prediction of behavior through the constructs that make up the theory of planned behavior), REME, 4(7). [online] Available at: http://reme.uji.es/articulos/abreva7191302101/texto. html [Accessed: 23 October 2017] (in Spanish)

Cadavid, L., Díez-Echavarría, L., Valencia, A. (2017) "Spin-off activities at higher educational institutions: Performance implications from a modeling perspective", Journal of Developmental Entrepreneurship, 22(2), Article number: 1750013. https://doi.org/10.1142/S1084946717500133

Calvo-Porral, C., Martínez-Fernández, V. A., Juanatey-Boga, O. (2013) "Análisis de dos modelos de ecuaciones estructurales alternativos para medir la intención de compra" (Analysis of two models of alternative structural equations to measure purchase intention), Revista Investigación Operacional, 34(3), pp. 230-243. [online] Available at: http://rev-inv-ope.univ-paris1.fr/fileadmin/rev-inv-ope/ files/34313/34313-05.pdf [Accessed: 13 January 2017] (in Spanish)

Davey, T., Plewa, C., Struwig, M. (2011) "Entrepreneurship perceptions and career intentions of international students", Education + Training, 53(5), pp. 335-352. https://doi.org/10.1108/00400911111147677

Díaz-Casero, J. C., Ferreira, J. J. M., Mogollón, R. H., Raposo, M. L. B. (2012) "Influence of institutional environment on entrepreneurial intention: a comparative study of two countries university students", International Entrepreneurship and Management Journal, 8(1), pp. 55-74. https://doi.org/10.1007/s11365-009-0134-3
Echeverri-Sánchez, L., Valencia-Arias, A., Benjumea-Arias, M., BarreraDel Toro, A. (2018) "Factores que inciden en la intención emprendedora del estudiantado universitario: Un análisis cualitativo" (Factors that affect the entrepreneurial intention of university students: A qualitative analysis), Revista Electrónica Educare, 22(2), pp. 1-19. (in Spanish) https://doi.org/10.15359/ree.22-2.10

González, C., Scublinsky, D. (2011) "Acerca de la validación de escalas y cuestionarios" (About the validation of scales and questionnaires), Revista Argentina de Reumatología, 22(2), pp. 6-8. (in Spanish)

Hair, J. F., Anderson, R. E., Tatham, R. L., Black, W. C. (2001) "Análisis Multivariante" (Multivariate analysis), Prentice Hall Iberia, Madrid, Spain. (in Spanish)

Hattab, H. W. (2014) "Impact of Entrepreneurship Education on Entrepreneurial Intentions of University Students in Egypt", Journal of Entrepreneurship, 23(1), pp. 1-18. https://doi.org/10.1177/0971355713513346

Hawkins, J. D., Weis, J. G. (1985) "The social development model: An integrated approach to delinquency prevention", The Journal of Primary Prevention, 6(2), pp. 73-97. https://doi.org/10.1007/BF01325432

Hernández-López, D. M., Moncada-Toro, J. F., Henao-Colorado, L. C. (2018) "Intención emprendedora de los empleados del sector privado de la ciudad de Medellín y su Área Metropolitana" (Entrepreneurial intention of the employees of the private sector of the city of Medellín and its metropolitan area), Revista CEA, 4(7), pp. 13-33. [online] Available at: https://revistas.itm.edu.co/index.php/revista-cea/article/ view/1045 [Accessed: 21 October 2018] (in Spanish)

Herrington, M., Kew, J., Simre, M., Turton, N. (2011) "Global entrepreneurship monitor South Africa", University of Cape Town Centre for Innovation and Entrepreneurship, Cape Town, South Africa.

Hong, Z., Hong, T., Cui, Z., Luzhuang, W. (2012) "Entrepreneurship Quality of College Students Related to Entrepreneurial Education: Empirical Study on Psychological and Behavioral Characteristics", Energy Procedia, 17, pp. 1907-1913. https://doi.org/10.1016/j.egypro.2012.02.331

Iakovleva, T., Kolvereid, L., Stephan, U. (2011) "Entrepreneurial intentions in developing and developed countries", Education + Training, 53(5), pp. 353-370. https://doi.org/10.1108/00400911111147686

Jones, P., Miller, C., Jones, A., Packham, G., Pickernell, D., Zbierowski, P. (2011) "Attitudes and motivations of Polish students towards entrepreneurial activity", Education + Training, 53(5), pp. 416-432. https://doi.org/10.1108/00400911111147721

Mangin, J. P. L., Fuentes, M. T. M., Gonzáles, M. V. R. (2006) "Optimización según estructuras de covarianzas" (Optimization according to covariance structures), In: Mallou, J. V., Mangin, J. P. L. (eds.) Modelización con estructuras de covarianzas en ciencias sociales (Modeling with covariance structures in social sciences), Netbiblo, A Coruña, Spain, pp. 11-30. (in Spanish) [online] Available at: https://dialnet.unirioja. es/servlet/articulo?codigo=4703924 [Accessed: 23 October 2017] 
Liñán, F., Fayolle, A. (2015) "A systematic literature review on entrepreneurial intentions: citation, thematic analyses, and research agenda", International Entrepreneurship and Management Journal, 11(4), pp. 907-933. https://doi.org/10.1007/s11365-015-0356-5

Liñán, F., Nabi, G., Krueger, N. (2013) "British and Spanish Entrepreneurial Intentions: A Comparative Study", Revista de Economía Mundial, 33, pp. 73-103. [online] Available at: https://dialnet.unirioja.es/servlet/articulo?codigo=4500943 [Accessed: 20 January 2018]

Londoño-Patiño, J. A., Acevedo-Álvarez, C. A. (2018) "El aprendizaje organizacional $(\mathrm{AO})$ y el desempeño empresarial bajo el enfoque de las capacidades dinámicas de aprendizaje" (Organizational learning $(\mathrm{OA})$ and business performance under the dynamic learning capabilities approach), Revista CEA, 4(7), pp. 103-118. (in Spanish) https://doi.org/10.22430/24223182.762

López-Roldán, P., Fachelli, S. (2015) "Análisis de tablas de contingencia" (Analysis of contingency tables), In: Metodología de la investigación social cuantitativa, Universitat Autònoma de Barcelona, Barcelona, Spain, pp. 1-114. (in Spanish) [online] Available at: http://ddd. uab.cat/pub/caplli/2015/131469/metinvsoccuan_cap3-6a2015.pdf [Accessed: 19 March 2018]

Maresch, D., Harms, R., Kailer, N., Wimmer-Wurm, B. (2016) "The impact of entrepreneurship education on the entrepreneurial intention of students in science and engineering versus business studies university programs", Technological Forecasting and Social Change, 104, pp. 172-179.

https://doi.org/10.1016/j.techfore.2015.11.006

Marques, C. S., Ferreira, J. J., Gomes, D. N., Gouveia Rodrigues, R. (2012) "Entrepreneurship education: How psychological, demographic and behavioural factors predict the entrepreneurial intention", Education + Training, 54(8/9), pp. 657-672. https://doi.org/10.1108/00400911211274819

Marulanda Valencia, F. Á., Montoya Restrepo, I. A., Vélez Restrepo, J. M. (2014) "Teorías motivacionales en el estudio del emprendimiento" (Motivational theories in the study of entrepreneurship), Pensamiento \& Gestión, 36, pp. 204-236. (in Spanish) https://doi.org/10.14482/pege.36.5571

Mejía Ordoñez, J. P., Arias Marín, C. M., Echeverri Sánchez, L. C. (2017) "El papel de la educación en creación de empresas en el contexto universitario a partir de los estudios registrados en Scopus" (The role of education in the creation of companies in the university context based on the studies registered in Scopus), Revista CEA, 3(5), pp. 69-87. (in Spanish) https://doi.org/10.22430/24223182.651

Mora, H. (2005) "Complementación de métodos en investigación social: Una reflexión en torno a las implicancias teóricas y las prácticas metodológicas" (Complementation of methods in social research: A reflection on the theoretical implications and methodological practices), Revista Anthropos, 207, pp. 73-96. (in Spanish) [online] Available at: http://hdl.handle.net/10925/877 [Accessed: 18 August 2017]

Moreno-Agudelo, J. A., Valencia-Arias, J. A. (2017) "Factores implicados en la adopción de software libre en las Pyme de Medellín" (Factors involved in the adoption of free software in the SMEs of Medellín), Revista CEA, 3(6), pp. 55-75. (in Spanish) https://doi.org/10.22430/24223182.673
Naktiyok, A., Karabey, C. N., Gulluce, A. (2010) "Entrepreneurial self-efficacy and entrepreneurial intention: the Turkish case", International Entrepreneurship and Management Journal, 6(4), pp. 419-435. https://doi.org/10.1007/s11365-009-0123-6

Ortiz-Delgadillo, G., Esquivel-Aguilar, E. O., Hernández-Castorena, O. (2017) "El impacto de la relación con el cliente y de la capacidad de valor agregado en el servicio en el rendimiento de la Pyme Manufacturera en Aguascalientes" (The impact of the relationship with the client and the capacity of added value in the service in the performance of the Manufacturing SME in Aguascalientes), Revista CEA, 2(4), pp. 47-58. (in Spanish) https://doi.org/10.22430/24223182.171

Packham, G., Jones, P., Miller, C., Pickernell, D., Thomas, B. (2010) "Attitudes towards entrepreneurship education: a comparative analysis", Education + Training, 52(8/9), pp. 568-586. https://doi.org/10.1108/00400911011088926

Peterman, N. E., Kennedy, J. (2003) "Enterprise Education: Influencing Students' Perceptions of Entrepreneurship", Entrepreneurship Theory and Practice, 28(2), pp. 129-144. https://doi.org/10.1046/j.1540-6520.2003.00035.x

Rae, D. (2010) "Universities and enterprise education: responding to the challenges of the new era", Journal of Small Business and Enterprise Development, 17(4), pp. 591-606. https://doi.org/10.1108/14626001011088741

Sampedro, I. R., Fernández-Laviada, A., Herrero Crespo, Á. (2013) "Aplicación de la teoría de la acción razonada al ámbito emprendedor en un contexto universitario" (Application of the theory of reasoned action to the entrepreneurial sphere in a university context), Investigaciones Regionales, 26, pp. 141-158. (in Spanish) [online] Available at: https://www.redalyc.org/articulo.oa?id=28928246007 [Accessed: 18 August 2017]

Sánchez García, J. C., Lanero Carrizo, A., Yurrebaso, A. (2005) "Variables determinantes de la intención emprendedora en el contexto universitario" (Determinant variables of entrepreneurial intention in the university context), Revista de Psicología Social Aplicada, 15(1-2), pp. 37-60. (in Spanish) [online] Available at: https://dialnet.unirioja.es/ servlet/articulo?codigo=2282152 [Accessed: 19 March 2017]

Sánchez Ramos, M. Á. (2005) "Uso metodológico de las tablas de contingencia en la Ciencia Política" (Methodological use of the contingency tables in Political Science), Espacios Públicos, 8(16), pp. 60-84. (in Spanish) [online] Available at: http://www.redalyc.org/ pdf/676/67681605.pdf [Accessed: 23 August 2017]

Schifter, D. E., Ajzen, I. (1985) "Intention, perceived control, and weight loss: an application of the theory of planned behavior", Journal of Personality and Social Psychology, 49(3), pp. 843-851. [online] Available at: https://www.ncbi.nlm.nih.gov/pubmed/4045706 [Accessed: 19 December 2017]

Solesvik, M. Z. (2013) "Entrepreneurial motivations and intentions: investigating the role of education major", Education + Training, 55(3), pp. 253-271. https://doi.org/10.1108/00400911311309314 
Soria-Barreto, K., Zuniga-Jara, S., Ruiz-Campo, S. (2016a)"Educación eintención emprendedora en estudiantes universitarios: un caso de estudio" (Education and entrepreneurial intention in university students: a case study), Formación Universitaria, 9(1), pp. 25-34. (in Spanish) https://doi.org/10.4067/S0718-50062016000100004

Soria-Barreto, K., Zuñiga-Jara, S., Ruíz-Campo, S. (2016b) "Determinantes de la intención emprendedora: nueva evidencia" (Determinants of entrepreneurial intention: new evidence), Interciencia, 41(5), pp. 325-329. (in Spanish). [online] Available at: http://www.redalyc.org/articulo.oa?id=33945552006 [Accessed: 18 July 2017]

Souitaris, V., Zerbinati, S., Al-Laham, A. (2007) "Do entrepreneurship programmes raise entrepreneurial intention of science and engineering students? The effect of learning, inspiration and resources", Journal of Business Venturing, 22(4), pp. 566-591. https://doi.org/10.1016/j.jbusvent.2006.05.002

Torres Velásquez, J. A., Valencia Arias, A., Bermúdez Hernández, J., Díez-Echavarría, L. F., Urrego Marín, M. L., Maussa Pérez, F. O. (2018) "Characterization of entrepreneurial intention in university students as from Systemic Entrepreneurship Intention Model: a case study", Revista Cuadernos de Gestión, 18(2), pp. 95-114. https://doi.org/10.5295/cdg.160670jt

Tshikovhi, N., Shambare, R. (2015) "Entrepreneurial knowledge, personal attitudes, and entrepreneurship intentions among South African Enactus students", Problems and Perspectives in Management, 13(1), pp. 152-158. [online] Available at: https://businessperspectives.org/pdfproxy.php?item_id:6476 [Accessed: 18 August 2017]
Valencia-Arias, A., Chalela-Naffah, S., Bermúdez-Hernández, J. (2019) "A proposed model of e-learning tools acceptance among university students in developing countries", Education and Information Technologies, 24(2), pp. 1057-1071. https://doi.org/10.1007/s10639-018-9815-2

van Dam, K., Schipper, M., Runhaar, P. (2010) "Developing a competency-based framework for teachers' entrepreneurial behaviour", Teaching and Teacher Education, 26(4), pp. 965-971. https://doi.org/10.1016/J.TATE.2009.10.038

Van Gelderen, M., Kautonen, T., Fink, M. (2015) "From entrepreneurial intentions to actions: Self-control and action-related doubt, fear, and aversion", Journal of Business Venturing, 30(5), pp. 655-673. https://doi.org/10.1016/j.jbusvent.2015.01.003

Villa, E., Ruiz, L., Valencia, A., Picón, E. (2018) "Electronic Commerce: Factors Involved in its Adoption from a Bibliometric Analysis", Journal of Theoretical and Applied Electronic Commerce Research, 13(1), pp. 39-70. https://doi.org/10.4067/S0718-18762018000100104

Yurrebaso Macho, A. (2012) "La personalidad y los valores sociales: influencia en el emprendizaje" (Personality and social values: influence on entrepreneurship), $\mathrm{PhD}$ Thesis, Universidad de Salamanca. (in Spanish) [online] Available at: https://gredos.usal. es/jspui/handle/10366/121234 [Accessed: 15 March 2017] 